\title{
RECENT STUDIES ON THERMODYNAMIC PROCESSES IN NANO-CERAMIC THERMAL INSULATION COATINGS
}

\author{
David BOZSAKY ${ }^{*}$ \\ Department of Architecture and Building Construction, Faculty of Architecture \\ Civil Engineering and Transport Sciences, Széchenyi István University \\ Egyetem tér 1, H-9026 Györ, Hungary, e-mail: bozsaky@gmail.com
}

Received 26 February 2018; accepted 4 September 2018

\begin{abstract}
Among nanotechnology-based thermal insulation materials thermodynamic performance of nano-ceramic coatings generates intensive discussions. Complete agreement has not been found yet about the mechanism of their insulating effect. In the Laboratory of Building Materials and Building Physics at Széchenyi István University (Györ, Hungary) heat transfer resistance experiments have been performed in order to describe thermodynamic processes inside nano-ceramic coatings. Previous studies finding after new measurements conducted in 2016-2017 also supported the former assumption that in case of nano-ceramic coatings convective heat transfer coefficient might be taken into account in a different way. Results also showed that thermal insulating effect of nano-ceramic coatings could be caused by a relatively high surface heat transfer resistance.
\end{abstract}

Keywords: Nanotechnology, Nano-ceramics, Thermal insulation, Thermodynamics

\section{Introduction}

The appearance of nanotechnology-based materials on the market of building materials opened several possibilities in the 1990s and made it possible to use them in architecture and civil engineering. Nano-silica additives can increase durability and compressive strength of cement-based materials [1]. They can be used to increase fluidity or water permeability of concrete structures [2], [3]. Tensile and bending strength of concrete structures can be enhanced by adding nanotubes or nano-fibers [1], [3]. Wood-based products composed with nanotubes or nano-fibers are twice as strong

\footnotetext{
${ }^{*}$ Corresponding Author
} 
as steel [1]. Coatings containing nanoparticles in the form of titanium dioxide $\left(\mathrm{TiO}_{2}\right)$, they are used to build up self-cleaning surfaces (e.g. floors, facades) [1], [3]. Nanoparticle-based coatings can also provide better adhesion, transparency, corrosion and fire protection [1], [4], [5].

In building industry a variety of nanotechnology-based thermal insulation materials could be encountered: grey-colored expanded polystyrene products including graphite powder additive or soot particles (e.g. EPS Graphite); Vacuum Insulation Panels (VIPs); aerogel insulations and thermal insulation coatings consisting hollow nano-ceramic microspheres. One of the principal topics of sustainable construction is to minimize or eliminate the negative effects on environment, which became a point of interest of civil engineers, architects, designers and researchers [6]. The variety of insulating products offers many options to use them effectively in housing. Nanotechnology-based thermal insulation materials are generally considered to have better thermal insulation quality than traditional materials. In their nanostructure one or more ways of heat transport is hampered, thus they can decrease the heat transfer coefficient of building structures. Thanks to their beneficial properties these high-performance thermal insulation materials can provide adequate thermal insulating effect with a relatively low structural thickness.

\section{Nano-ceramic coatings}

Most paint-on insulation products contain microscopic vacuum-hollow ceramic microspheres with a diameter of $20-120 \mu \mathrm{m}$ and with a cellular wall thickness of 50-200 nm. They are called Nano-Ceramic Coatings (NCC).

Synthetizing of nano-ceramic microspheres was developed in 1984 by S. Komarneni and R. Roy. This process is called 'sol-gel' and enabled researchers to test the properties of nano-ceramics [7]. To produce nano-ceramics at a more efficient way this process was later replaced by microwave sintering [8].

NCCs are made of melted glass or ceramics under high gas-pressure and at a high temperature $\left(1500{ }^{\circ} \mathrm{C}\right)$. After cooling down, the pressure ends, leaving vacuum inside the microspheres. A mixture of synthetic rubber and other polymers is used as binding materials. Their main components are styrene (20\%) and acryl latex (80\%). Styrene enhances mechanical strength and acryl latex makes nano-ceramic coating resistant against weather conditions and provides flexibility. Other additives (e.g. biocides, antifouling and antifungal materials) make the final product durable and mould-proof [9], [10], [11].

NCCs are typically used for exterior and interior wall insulation, but they are also suitable for pipe insulation and protection against fire and corrosion. They can be easily transmitted to hard-to-reach places [9], [10], [11].

\section{Research history}

Thermodynamic properties of NCCs generally generate intensive discussions in academic circles because of contradictory technical data that could be found in special 
literature and in producers' handouts. The excellent thermal insulating quality of NCC is usually associated with an extremely low thermal conductivity [9], [10], [11].

\subsection{Literature summary}

Special literature provides different data regarding thermal insulation quality and thermodynamic details of NCCs [12], [13]. Some sources state that their thermal conductivity is around $0.001-0.003 \mathrm{~W} / \mathrm{mK}$ based on measurements of university laboratories in Latvia, Russia (Volgograd) and Hungary (Debrecen) [4], [5], [9], [10], [11]. Other sources publish much higher values (from $0.014 \mathrm{~W} / \mathrm{mK}$ to $0.140 \mathrm{~W} / \mathrm{mK}$ ) [5], [14], [15], [16] and talk about their effective thermal conductivity [14], [16], which contains the internal convective heat transfer coefficient $\left(h_{i}\right)$ and external convective heat transfer coefficient $\left(h_{e}\right)$ of the enclosed nano-scale pores inside the nanostructure. These details are often not confirmed by documented laboratory tests or refer to insufficiently introduced experiments [9], [10], [11]. Others calculate thermal conductivity of nano-ceramic coatings from heat transfer coefficient ( $U$-value) of a global building structure [14]. Each method has the same problem that it tries to determine thermal conductivity indirectly using conventional data and calculations and it does not take into account that physical and chemical processes inside structures ranging from 1 to 100 nano-meters can occur differently than in traditional macro sizes.

In order to test thermal performance of nano-ceramic coatings energy balance was investigated in periods of heating and also in the summer on external building surfaces using dynamic outdoor testing. Measurements demonstrated that coatings consisting of hollow ceramic microspheres have the same thermodynamic properties as standard facing coatings [17], [18]. Spectral emissivity properties and reflective ability of nanoceramic thermal insulation coatings were also measured with standard infrared spectroscopy and a handheld reflection intensity measurement device. Measured data demonstrated that coatings have the same radiant properties as standard building coatings [19], [20]. Based on GOST 23630.2-79 (Russian standard) using an IT- $\lambda-400$ instrument thermal conductivity of nano-ceramic coatings consisting hollow inorganic microspheres measured to be $0.10-0.18 \mathrm{~W} / \mathrm{mK}$ and the effective thickness of the thinfilm insulation coating was determined at least $5 \mathrm{~mm}$ (that requires application of 4 layers of material at each layer thickness of 1-1.5 mm) [15].

Other researchers claim that thermal insulation coatings can highly increase heat transfer resistance of the insulated surface by reducing convective heat transfer coefficient [16]. Experiments have shown that they are able to improve the heat transfer coefficient of solid brick masonry [14].

\subsection{Former experiments at Széchenyi István University (Experiment 1-3)}

After studying the special literature three experiments were performed in the Laboratory of Building Materials and Building Physics at Széchenyi István University (Győr, Hungary) in 2014-2017. Results of Experiment 1, Experiment 2 and Experiment 3 were published in 2015-2016 [21], [22], [23]. Their results founded Experiment 4 that is the base of the present study. In order to understand it better it is important to summarize the former results of Experiments 1-3. 
In Experiment 1 five types (Type 1-5) of samples were made from different kinds of traditional thermal insulation materials: Expanded PolyStyrene (EPS), eXtruded PolyStyrene (XPS) and Oriented Strand Board (OSB). Sample Type 1 was uncoated and homogeneous, other samples were sprayed with a nano-ceramic coating. Thermal conductivity of homogeneous samples and the effective thermal conductivity $\left(\lambda_{\text {eff }}\right)$ of inhomogeneous samples (Type 2-5) were compared and the results seemed to show a minor negative effect of nano-ceramic coating on thermal insulation quality [21], [22]. Only XPS samples showed a small positive effect with an insignificant decreasing value [21], [22].

During Experiment 2 thermal conductivity of the pure nano-ceramic coating was measured directly with a standard heat flow meter on samples with a thickness of $20 \mathrm{~mm}$. The average thermal conductivity under air-dry conditions was $0.0690 \mathrm{~W} / \mathrm{mK}$. However; NCCs are practically not used with a thickness of $20 \mathrm{~mm}$, because they are applied as a thin membrane. Therefore it could not be clearly declared that thermal conductivity of this material has the same thermal conductivity if it is used as a very thin membrane [21], [22].

Based on the previous two experiments it was concluded that insulating effect of nano-ceramic thermal insulation coatings is probably not caused by their extremely low thermal conductivity. As it was formerly mentioned, some sources claim that insulating effect of these materials is generated by not their extremely low thermal conductivity (this value is estimated to be $0.014 \mathrm{~W} / \mathrm{mK}$ ) but by their high surface heat transfer resistance.

Considering it as a basic concept Experiment 3 was conducted in 2015-2016. For this experiment 12 different orders of layers were constructed from 300x300 mm samples of thermal insulation materials of different thicknesses. There were coated and uncoated samples; moreover, a 100x100 mm air gap with a thickness of 20 and $30 \mathrm{~mm}$ was included into the construction. Results seemed to prove that the insulating effect comes from a relatively high surface heat transfer resistance. However; the insulating effect was much lower than previously expected [23].

\section{Recent studies (Experiment 4)}

Supposing that in a larger air gap, air particles should have more possibility for bulk movements; surface heat transfer resistance can prevail and higher differences may arise between coated and uncoated samples Experiment 4 was conducted in 2016-2017.

For Experiment 4 the same 12 orders of layers were used as in Experiment 3. Although the samples were constructed from 300x300 mm samples of Thermal Insulation Materials (TIM) of different thicknesses, but with a 200x200 mm Air Gap (AG) with a thickness of 20 and $30 \mathrm{~mm}$. There were configurations (Table I), which contained NCC and uncoated samples as well (Type 1-12).

Samples were prepared by the manufacturing company that provided only approximate data about the raw material. The composition is patented and manufacturers generally do not give highly accurate details about the product. It can definitely be stated that the examined coating was outside façade insulation. Wide limits $(20-50 \mathrm{~m} / \mathrm{m} \%)$ were given about the ratio of the binder material, but certainly it neared 
the lower limit because coating was sprayed on the surface of samples and low ratio of binder material is ideal for spray technology.

\section{Table I}

Types of sample configurations for Experiment 4

\begin{tabular}{|l|l|}
\hline Type 1 & $20 \mathrm{~mm} \mathrm{AG}+$ TIM \\
Type 2 & $20 \mathrm{~mm} \mathrm{AG}+2 \mathrm{~mm} \mathrm{NCC}+\mathrm{TIM}$ \\
Type 3 & $30 \mathrm{~mm} \mathrm{AG}+\mathrm{TIM}$ \\
Type 4 & $30 \mathrm{~mm} \mathrm{AG}+2 \mathrm{~mm} \mathrm{NCC}+\mathrm{TIM}$ \\
Type 5 & TIM $+20 \mathrm{~mm} \mathrm{AG}+\mathrm{TIM}$ \\
Type 6 & TIM $+2 \mathrm{~mm} \mathrm{NCC}+20 \mathrm{~mm} \mathrm{AG}+\mathrm{TIM}$ \\
Type 7 & TIM $+30 \mathrm{~mm} \mathrm{AG}+\mathrm{TIM}$ \\
Type 8 & TIM $+2 \mathrm{~mm} \mathrm{NCC}+30 \mathrm{~mm} \mathrm{AG}+\mathrm{TIM}$ \\
Type 9 & $20 \mathrm{~mm} \mathrm{AG}+\mathrm{TIM}+20 \mathrm{~mm} \mathrm{AG}$ \\
Type 10 & $20 \mathrm{~mm} \mathrm{AG}+2 \mathrm{~mm} \mathrm{NCC}+\mathrm{TIM}+2 \mathrm{~mm} \mathrm{NCC}+20 \mathrm{~mm} \mathrm{AG}$ \\
Type 11 & $30 \mathrm{~mm} \mathrm{AG}+\mathrm{TIM}+30 \mathrm{~mm} \mathrm{AG}$ \\
Type 12 & $30 \mathrm{~mm} \mathrm{AG}+2 \mathrm{~mm} \mathrm{NCC}+\mathrm{TIM}+2 \mathrm{~mm} \mathrm{NCC}+30 \mathrm{~mm} \mathrm{AG}$ \\
\hline
\end{tabular}

According to EN 12667:2001 standard [24] (Thermal performance of building materials and products. Determination of thermal resistance by means of guarded hot plate and heat flow meter methods products of high and medium thermal resistance.) Taurus TCA 300 heat flow meter was used for measurements. The heat flow is induced by electrical heating using a resistor heater having a direct thermal contact with the surface of the sample [25]. Because of the inhomogeneous, multi-layer structure heat flow meter was able to determine effective thermal conductivity $\left(\lambda_{\text {eff }}\right)$ [26]. Effective thermal conductivity of 3-3 pieces of each type of configurations was measured using 3 different kinds of thermal insulation materials: EPS, XPS and OSB plates. Each sample was measured 3 times. Moreover; sample Types 1-8 were measured in two ways; firstly NCC was on the warm side; secondly NCC was on the cold side. Eventually a total number of 192 different measurements were conducted.

The experiment was to provide information about thermal insulation ability of NCC. Therefore the main focus of experiments was the difference in effective thermal conductivity between coated and uncoated samples. Compared to Experiment 3 the only difference in the configurations was the multiple increased air gaps. Therefore measurements of Experiment 4 were also compared with the results of Experiment 3. Because of the increased air gap larger changes were expected in effective thermal conductivity of coated and uncoated samples.

This assumption was partly proven because differences between coated and uncoated samples were really higher than in Experiment 3. It is well-known that the accuracy of Taurus TCA heat flow meter is up to $5 \%$ and these results might be due to the fluctuations in measurement limits. However, in fact, in $91 \%$ there were no deviations between the 3 test results of an individual sample, and in $9 \%$ the difference was only $\pm 0.0002 \mathrm{~W} / \mathrm{mK}$, which means $0.1-0.3 \%$ accuracy.

Changes in EPS samples were the most apparent (Table II). The most significant difference $(9.96 \%$ and $12.04 \%$ ) was found in configuration Types 9-12 due to the twosided nano-ceramic coating. As it was formerly expected, higher changes were 
registered than in Experiment 3. In case of Types 1-4 the change level was also higher $(6.62 \%$ and $6.02 \%)$ than in Experiment 3. Effective thermal conductivity changes were also the lowest in case of Types 5-8 (4.55\% and 5.02\%), but these data were nearly similar to the results of Experiment 3. A possible explanation of this phenomenon can be that if an air gap is closed inside two layers of thermal insulation then air particles are less able to move and the effect of surface heat transfer resistance becomes smaller. It can be also concluded that the application of NCC in this way could be the least efficient. There was no difference between measurement results depending on the location of the coating (warm or cold side).

\section{Table II}

Results of Experiment 3 and Experiment 4 with EPS samples

\begin{tabular}{|c|c|c|c|c|}
\hline \multirow[t]{2}{*}{$\begin{array}{l}\text { Sample } \\
\text { type }\end{array}$} & \multicolumn{2}{|c|}{$\begin{array}{c}\text { Experiment } 3 \\
\text { (100x100 mm air gap) }\end{array}$} & \multicolumn{2}{|c|}{$\begin{array}{c}\text { Experiment } 4 \\
\text { (200x200 mm air gap) }\end{array}$} \\
\hline & $\begin{array}{c}\lambda_{\text {eff }} \\
(\mathrm{W} / \mathrm{mK}) \\
\end{array}$ & $\begin{array}{l}\Delta \lambda_{\text {eff }} \\
(\%)\end{array}$ & $\begin{array}{c}\lambda_{\text {eff }} \\
(\mathrm{W} / \mathrm{mK})\end{array}$ & $\begin{array}{l}\Delta \lambda_{\text {eff }} \\
(\%)\end{array}$ \\
\hline $\begin{array}{l}1 \\
2\end{array}$ & $\begin{array}{l}0.06702 \\
0.06312\end{array}$ & -5.82 & $\begin{array}{l}0.06284 \\
0.05868\end{array}$ & -6.62 \\
\hline $\begin{array}{l}3 \\
4\end{array}$ & $\begin{array}{l}0.08272 \\
0.07796\end{array}$ & -5.75 & $\begin{array}{l}0.07919 \\
0.07442\end{array}$ & -6.02 \\
\hline $\begin{array}{l}5 \\
6 \\
\end{array}$ & $\begin{array}{l}0.05469 \\
0.05209\end{array}$ & -4.75 & $\begin{array}{l}0.05585 \\
0.05331 \\
\end{array}$ & -4.55 \\
\hline $\begin{array}{l}7 \\
8\end{array}$ & $\begin{array}{l}0.06211 \\
0.05903\end{array}$ & -4.96 & $\begin{array}{l}0.06613 \\
0.06281\end{array}$ & -5.02 \\
\hline $\begin{array}{c}9 \\
10 \\
\end{array}$ & $\begin{array}{l}0.08583 \\
0.07840\end{array}$ & -8.66 & $\begin{array}{l}0.07759 \\
0.06986 \\
\end{array}$ & -9.96 \\
\hline $\begin{array}{l}11 \\
12\end{array}$ & $\begin{array}{l}0.10923 \\
0.10028\end{array}$ & -8.19 & $\begin{array}{l}0.10830 \\
0.09526\end{array}$ & -12.04 \\
\hline
\end{tabular}

In case of XPS samples smaller changes can be observed (Table III) similarly to Experiment 3. This could be explained by the results of Experiment 1 where nanoceramic coating itself resulted in the reduction of thermal conductivity. This is why surface heat transfer resistance seems to have a minor effect on thermal insulation quality. The most significant thermal conductivity changes were in configurations Types 1-4 (4.49\% and 4.70\%). Configurations Types 9-12 showed also higher changes than in Experiment 3 but the increase was not as significant as in case of EPS samples $(3.71 \%$ and $4.92 \%)$. Just like EPS samples, a little bit lower changes were measured in case of Types $5-8(3.30 \%$ and $3.80 \%)$ and there were nearly no differences between Experiment 3 and Experiment 4. There was also no difference between measurement results depending on the location of the coating (warm or cold side).

In case of OSB boards the insulating effect of nano-ceramic coating was undetectable (Table IV). Except the sample Type 12, all measurements showed that coating has a negative effect on thermal insulation quality. In Experiment 3 the smallest change rate was in case of Type 12, too, but the effect was still destructive. In Experiment 4 the sample Type 12 had almost no changes in effective thermal conductivity $(-0.02 \%)$. Similarly to Experiment 3 the effective thermal conductivity of 
configurations Types 1-11 became higher when using NCC. Moreover configuration Types 1-6 suffered major changes $(3.84 \%, 3.77 \%, 3.08 \%)$. Configurations Types 7-11 suffered slightly smaller changes than in Experiment 3, but the results still showed that coating has a destructive effect on thermal insulation quality.

\section{Table III}

Results of Experiment 3 and Experiment 4 with XPS samples

\begin{tabular}{|c|c|c|c|c|}
\hline \multirow[t]{2}{*}{$\begin{array}{l}\text { Sample } \\
\text { type }\end{array}$} & \multicolumn{2}{|c|}{$\begin{array}{c}\text { Experiment } 3 \\
\text { (100x100 mm air gap) }\end{array}$} & \multicolumn{2}{|c|}{$\begin{array}{c}\text { Experiment } 4 \\
(200 \times 200 \mathrm{~mm} \text { air gap })\end{array}$} \\
\hline & $\begin{array}{c}\lambda_{\text {eff }} \\
(\mathrm{W} / \mathrm{mK})\end{array}$ & $\begin{array}{l}\Delta \lambda_{\text {eff }} \\
(\%)\end{array}$ & $\begin{array}{c}\lambda_{\text {eff }} \\
(\mathrm{W} / \mathrm{mK})\end{array}$ & $\begin{array}{l}\Delta \lambda_{\text {eff }} \\
(\%)\end{array}$ \\
\hline 1 & 0.05144 & 10 & 0.04761 & 440 \\
\hline 2 & 0.04933 & -4.10 & 0.04547 & -4.49 \\
\hline 3 & 0.06220 & 226 & 0.05910 & 470 \\
\hline 4 & 0.06011 & -3.50 & 0.05632 & $-4 . / 0$ \\
\hline 5 & 0.04556 & 315 & 0.04660 & 320 \\
\hline 6 & 0.04397 & $-3.4 J$ & 0.04506 & -5.50 \\
\hline 7 & 0.05092 & & 0.05391 & \\
\hline 8 & 0.04921 & -5.30 & 0.05186 & -3.80 \\
\hline 9 & 0.06456 & 270 & 0.05641 & 271 \\
\hline 10 & 0.06276 & -2.19 & 0.05431 & -5.11 \\
\hline 11 & 0.08259 & 274 & 0.07689 & 407 \\
\hline 12 & 0.08033 & -2.14 & 0.07310 & -4.92 \\
\hline
\end{tabular}

Table IV

Results of Experiment 3 and Experiment 4 with OSB samples

\begin{tabular}{|c|c|c|c|c|}
\hline \multirow[t]{2}{*}{$\begin{array}{l}\text { Sample } \\
\text { type }\end{array}$} & \multicolumn{2}{|c|}{$\begin{array}{c}\text { Experiment } 3 \\
(100 \times 100 \mathrm{~mm} \text { air gap })\end{array}$} & \multicolumn{2}{|c|}{$\begin{array}{c}\text { Experiment } 4 \\
(200 \times 200 \mathrm{~mm} \text { air gap })\end{array}$} \\
\hline & $\begin{array}{c}\lambda_{\text {eff }} \\
(\mathrm{W} / \mathrm{mK})\end{array}$ & $\begin{array}{l}\Delta \lambda_{\text {eff }} \\
(\%)\end{array}$ & $\begin{array}{c}\lambda_{\text {eff }} \\
(\mathrm{W} / \mathrm{mK})\end{array}$ & $\begin{array}{l}\Delta \lambda_{\text {eff }} \\
(\%)\end{array}$ \\
\hline $\begin{array}{l}1 \\
2\end{array}$ & $\begin{array}{l}0.10630 \\
0.10972\end{array}$ & +3.22 & $\begin{array}{l}0.10494 \\
0.10897\end{array}$ & +3.84 \\
\hline $\begin{array}{l}3 \\
4 \\
\end{array}$ & $\begin{array}{l}0.12660 \\
0.12960 \\
\end{array}$ & +2.37 & $\begin{array}{l}0.12468 \\
0.12938 \\
\end{array}$ & +3.77 \\
\hline $\begin{array}{l}5 \\
6\end{array}$ & $\begin{array}{l}0.06810 \\
0.07003 \\
\end{array}$ & +2.83 & $\begin{array}{l}0.07164 \\
0.07385\end{array}$ & +3.08 \\
\hline $\begin{array}{l}7 \\
8 \\
\end{array}$ & $\begin{array}{l}0.07552 \\
0.07765 \\
\end{array}$ & +2.82 & $\begin{array}{l}0.08379 \\
0.08605\end{array}$ & +2.70 \\
\hline $\begin{array}{c}9 \\
10\end{array}$ & $\begin{array}{l}0.11800 \\
0.12070\end{array}$ & +2.29 & $\begin{array}{l}0.10643 \\
0.10873\end{array}$ & +2.16 \\
\hline $\begin{array}{l}11 \\
12\end{array}$ & $\begin{array}{l}0.15097 \\
0.15280\end{array}$ & +1.21 & $\begin{array}{l}0.14140 \\
0.14137\end{array}$ & -0.02 \\
\hline
\end{tabular}


Based on tests of samples with different materials (EPS, XPS and OSB) it can be concluded that probably, not the same material quality and composition is suitable for all building structures and materials. It can also be seen that thermal insulation quality depends on the material quality of the coated surface. It can also be stated that every time the correct solution should be found (materials quality, materials composition, etc.) and the same material is not suitable for all surfaces. Presumably, insulating OSB plates needs different material quality, composition or application technology than EPS and XPS plates to achieve significant insulating effect.

\section{Conclusions}

Former laboratory tests showed that nano-ceramic thermal insulation coatings probably do not have an extremely low thermal conductivity that was described by the available documents of producers and distributors. Their thermal conductivity is likely to be higher than that of traditional thermal insulation materials like mineral wool products or plastic foams (e.g. EPS, XPS and polyurethane foam).

Some special literature sources claim without referring to laboratory measurement results that their insulating effect comes from a relatively high surface heat transfer resistance.

Heat transfer resistance experiments in the Laboratory of Building Physics and Building Materials at Széchenyi István University (Győr, Hungary) were conducted to prove or disprove this hypothesis. Although it can be seen that the difference between coated and uncoated samples was significant in case of EPS and XPS, but insulating effect was not as high as it can be found in the special literature. On basis of Experiment 2 and 4 (where the only difference between samples was the coating itself) it could be concluded that the higher heat transfer resistance of coated samples caused the lower convective heat transfer coefficient. It can be declared that in case of nano-structured materials convective heat transfer coefficient might be taken into account differently than in case of traditional macro-structured thermal insulation materials.

Test results also showed that the same material quality, composition and application technology may not be suitable for insulating different kinds of surfaces.

Further studies are needed to confirm the insulation effect of nano-ceramic thermal insulation coatings. There are running experiments with new types of configurations containing a 200x200 mm air gap with a thickness of 50 and $80 \mathrm{~mm}$ (Experiment 5 and Experiment 6). Probably, in a larger air gap air particles should have more possibility for bulk movements. Thereby surface heat transfer resistance can prevail and higher differences may arise between coated and uncoated samples. These experiments are still running. Results will be reported in a subsequent study.

Furthermore, it would be important to make in-situ heat transfer experiments with $\mathrm{NCC}$ in order to understand the thermal insulation behavior of the material better. In order to achieve this goal heat transfer coefficient of several sample buildings should be measured without any thermal insulation. These basic data should be compared with the heat transfer coefficient of structures with NCC insulation. 


\section{Acknowledgements}

The author would like to acknowledge and thank the financial support of the project EFOP-3.6.1-16-2016-00017 - Internationalization, initiatives to establish a new source of researchers and graduates, and development of knowledge and technological transfer as instruments of intelligent specializations at Széchenyi István University.

\section{Open Access statement}

This is an open-access article distributed under the terms of the Creative Commons Attribution 4.0 International License (https://creativecommons.org/licenses/by/4.0/), which permits unrestricted use, distribution, and reproduction in any medium, provided the original author and source are credited, a link to the CC License is provided, and changes - if any - are indicated. (SID_1)

\section{References}

[1] Pacheco-Torgal F., Jalali S. Nanotechnology, Advantages and drawbacks in the field of construction and building materials, Construction and Building Materials, Vol. 25, No. 2, 2011, pp. 582-590.

[2] Lan W., Kexing F., Liang Y., Botao W. The application of ceramic coatings in petroleum chemical and building industries, International Conference on Material and Environmental Engineering, Jiujiang (Jiangxi), China, 21-24 March 2014, Atlantis Press, 2014, pp. 146-149.

[3] Abdelrahman M. Towards sustainable architecture with nanotechnology, Al-Azhar Engineering 11th International Conference, Cairo, Egypt, 21-23 December 2010, Paper 154.

[4] Orbán J. Use of nanotechnology in building industry, Part I. (in Hungarian), Magyar Épitéstechnika, No. 1, 2012, pp. 40-43.

[5] Orbán J. Use of nanotechnology in building industry, Part II. (in Hungarian), Magyar Épitéstechnika, No. 2-3, 2012, pp. 54-57.

[6] Porhinčák M., Eštoková A., Vilčeková S. Comparison of environmental impact of building materials of three residential buildings, Pollack Periodica, Vol. 6, No. 3, 2011, pp. 53-62.

[7] Hoffman D., Roy R., Komarneni S. Diphasic ceramic composites via a sol-gel method, Materials Letters, Vol. 2, No. 3, 1984, pp. 245-247.

[8] Sandberg L. I. C., Gao T., Jelle B. P., Gustavsen A. Synthesis of hollow silica nano-spheres by sacrificial polystyrene templates for thermal insulation applications, Advances in Material Science and Engineering, Vol. 2013, Article ID 483651, p. 6.

[9] Thermal insulating process of TSM ceramic coating, (in Hungarian) Thermogát Ltd, Budapest, 2017, http://tsmceramic.com/?modul=oldal\&tartalom=1196370, (last visited 14 May 2017).

[10] Exterior wall coats, SPM Thermo-Shield Inc, Naples (Florida, United States), 2017, http://www.thermoshield.com/index.html/thermoshieldexteriorwall.html, (last visited 5 May 2017).

[11] Thin-layer thermal protection (in Hungarian), MANTI Ceramic Ltd, Budaörs (Hungary), p. 20, 2016, https://www.manti.hu/press, (last visited 14 May 2017). 
[12] Paul G., Chopkar M., Manna I., Das P. K. Techniques for measuring the thermal conductivity of nano-fluids, A review, Renewable and Sustainable Energy Reviews, Vol. 14, No. 7, 2010, pp. 1913-1924.

[13] Koniorczyk P., Zmywaczyk J., Kowalski M. Experimental studies of thermal conductivity of the composite coating consisted of hollow ceramic microspheres, In: Walczok W. (Ed) 1st Scientific International Coating Congress, 4-5 November 2004, Berlin (Germany), 2004, p. 15.

[14] Lakatos Á. Examination of nanotechnology-based thermal insulation materials on solid brick masonry (in Hungarian), Energiagazdálkodás, Vol. 57, No 3-4, 2016, pp. 21-25.

[15] Chukhlanov V. Y., Trifonova T. A., Selivanov O. G., Ilina M. E., Chukhlanova N. V. Thinfilm coatings based on hollow inorganic microspheres and polyacrylic binder, International Journal of Applied Engineering Research, Vol. 12, No. 7, 2017, pp. 1194-1199.

[16] Orbán J. Reducing energy consumption of buildings with the help of thin heat protection coatings, Part II (in Hungarian), Magyar Épitéstechnika, No. 9, 2015, pp. 40-42.

[17] Čekon M. Thermodynamic properties of reflective coatings, Advanced Materials Research, Vol. 649, 2013, pp. 179-182.

[18] Čekon M., Kalousek M., Hraška J., Ingeli R. Spectral optical properties and thermodynamic performance of reflective coatings in a mild climate zone, Energy and Buildings, Vol. 77, 2014, pp. 343-354.

[19] Čekon M. Spectral emissivity properties of reflective coatings, Slovak Journal of Civil Engineering, Vol. 20, No. 2, 2012, pp. 1-7.

[20] Ádám L., Nagy B., Nemes R. Laboratory experiments and development possibilities of reflective coatings (in Hungarian), Megtérülö Épületenergetika, Vol. 3, No. 7, 2016, pp. 35-39.

[21] Bozsaky D. Laboratory test with liquid nano-ceramic thermal insulation coating, Procedia Engineering, Vol. 123, 2015, pp. 68-75.

[22] Bozsaky D. Thermal insulation with nanotechnology-based materials, In: H. Bruckner (Ed) Internationales Symposium Eventmaterials, TU Wien, Wien, Austria, 19-20 November 2015, 2015, pp. 137-154.

[23] Bozsaky D. Thermodynamic tests with nano-ceramic thermal insulation coatings, Pollack Periodica, Vol. 12, No. 1, 2017, pp. 135-145.

[24] Jerman M., Černý R. Properties of hydrophilic mineral wool Front-Rock Max E, Pollack Periodica, Vol. 4, No. 2, 2009, pp. 101-106.

[25] Pavlík Z., Jerman M., Trník A., Kočí V., Černý R. Effective thermal conductivity of hollow bricks with cavities filled by air and expanded polystyrene, Journal of Building Physics, Vol. 37, No. 4, 2014, pp. 436-448. 